\title{
Comparative Anatomical Study in the Genus Sambucus (Adoxaceae) Distributed in Turkey
}

\author{
Omer Elkiran ${ }^{1 *}$ \\ ${ }^{1 *}$ Sinop University, Vocational School of Health Services, Environmental Health Programme, Sinop, Turkey, (ORCID: 0000-0003-1933-4003), \\ omer_elkiran@hotmail.com
}

(First received 25 November 2021 and in final form 16 December 2021)

(DOI: 10.31590/ejosat.1028351)

ATIF/REFERENCE: Türkmenoğlu, G., Sarıkaya, A. G. \& Fakir, H. (2019). Phlomis grandiflora H. S. Thompson var. grandiflora ve Phlomis leucophracta P. H. Davis \& Hub.-Mor. Taksonlarının Farklı Toplama Zamanlarına Ait Uçucu Bileşenleri . Avrupa Bilim ve Teknoloji Dergisi , (31), 670-674.

\begin{abstract}
In this study, S. nigra L. and S. ebulus L. (Adoxaceae) species belonging to the Sambucus genus were examined. Species of the genus were collected from northern Turkey and anatomical comparisons were made. Stem and leaf anatomy were examined by light microscopy. The plants have woody stem anatomy. The druse crystals which are the main anatomical characters of the genus were observed in the examined taxa. Differences were found in the number of cells of the vascular bundles, the arrangement of the druze crystals, and the shapes of the abaxial and adaxial epidermis cells in the leaf. In addition, differences were observed in the margin shape and collenchyma cell numbers on the stem.
\end{abstract}

Keywords: Sambucus, Adoxaceae, Anatomy, Turkey.

\section{Türkiye'de Yayılış Gösteren Sambucus (Adoxaceae) Cinsinin Karşılaştırmalı Anatomisi}

$\ddot{O} z$

Bu çalışmada Sambucus cinsine ait S. nigra L. ve S. ebulus L. (Adoxaceae) türleri incelenmiştir. Cinsin türleri Türkiye'nin kuzeyinden toplanmış ve anatomik karşılaştırmalar yapılmıştır. Işık mikroskobu ile gövde ve yaprak anatomisi incelenmiştir. Bitkiler odunsu gövde anatomisine sahiptir. Cinsin anatomik ana karakteri olan kalsiyum oksalat kristalleri incelenen taksonlarda gözlenmiştir. Yaprakta iletim demetlerinin hücre sayıları, druz kristallerinin dizilişleri, alt ve üst epidermis hücrelerinin şekillerinde farklılıklar bulunmuştur. Ayrıca gövdede kenar şekli ve kollenkima hücre sayılarında farklılıklar gözlenmiştir. Sonuçlar cins içinde tartışılmış ve karşılaştırılmıştır.

Anahtar Kelimeler: Sambucus, Adoxaceae, Anatomi, Türkiye.

\footnotetext{
*Corresponding Author: omer_elkiran@hotmail.com
} 


\section{Introduction}

Sambucus (Adoxaceae) is a deciduous genus with a small number of taxa, in the form of shrubs or trees $[1,2]$. While Sambucus was previously included in the Caprifoliaceae family, it was later included in the Adoxaceae family according to the results of genetic and classification studies $[3,4]$.

Sambucus is a genus with difficult taxonomy. Representatives of the genus are geographically widespread, morphologically complicated and often present great variability within particular species [5]. Schwerin (1920) tentatively recognized 28 species and numerous varieties [6]. Bolli (1994) reduced the number of recognized species worldwide to nine [7, 8]. Turkey is very rich in terms of plant species due to its different climatic diversity [9]. There are two species in Turkey belonging to the genus Sambucus [10]. S. ebulus L. and S. nigra L. are perennial herb known locally as murver, sultanotu, sahmehlemi, agac murver and hekimana [10-12].

S. nigra is a plant with a sharp smell, 1-8 meters tall, in the form of a bush or tree. There are cracks and deep clefts in the bark and it is brown. The leaves are opposite, 5-7 ellipticallanceolate, and the leaflets are toothed. Its flowers are umbrellashaped and milky white in color. The fruits are black-purple shiny, spherical. The plant can be found at sea level or at higher levels, in forest or open areas (1400 m a.s.l.). The plant can grow in different parts of the world [13]. It is rarely seen in WesternNorthern European countries [14,15].

S. ebulus plant is a perennial herb with erect and unbranched stems, growing up to $1-2 \mathrm{~m}$ in height, with a rhizome root structure. The leaves of the plant are opposite each other, with 5 9 leaflets, 15-30 centimeters in length, hairy and fragrant. The stems bear flowers that are white (rarely pink) with a crown of 10-15 centimeter corimbo. The fruits are dark blue or purple in color. S. ebulus grows naturally in south-central Europe, northwest Africa, and southwest Asia throughout the world [16].

Since the Sambucus genus has medicinal properties, it is also used for healing purposes in diseases. Plants of this genus have a perspiration-increasing and diuretic effect [17,18]. And it is also used as a folk medicine in the treatment of intestinal disorders, flu infections and rheumatic diseases [2,17,19].

In the anatomical studies, it is noteworthy that the cranial tissue consisting of mesophyll and bundle sheaths, which are morphologically and functionally different, is found. Kranz tissue is widely used to explain the $\mathrm{C} 4$ photosynthetic phenomenon in anatomical studies in plants [20-22].

In literature, there is not any anatomical study on Sambucus species in naturally growing in Turkey. Therefore, I have encouraged to study the patterns of anatomical structure among Sambucus taxa. This paper is first report and aimed at comparison of anatomical difference of $S$. ebulus and $S$. nigra naturally growing in Sinop province located in North of Turkey.

\section{Material and Method}

\subsection{Plant Material}

The plant specimens were collected during spring and summer from natural habitats of Sinop, Turkey from 2020 (Table
1). The taxonomic identification of the plant was made using Flora of Turkey [23].

Table 1. Taxa used for anatomical studies and localities of specimen collection

Tablo 1. Anatomik çalışmalar için kullanılan taksonlar ve örnek toplama yerleri.

\begin{tabular}{ll}
\hline Taxa & Collection areas and collector's number \\
\hline S. nigra & $\begin{array}{l}\text { Turkey, A4, Sinop: Korucuk village, } \\
\text { roadside, 50m, 15.05.2020, ÖE-1150. } \\
\text { Turkey, A4, Sinop: Ordu village, roadside, } \\
\text { S. ebulus }\end{array}$ \\
& 20m, 16.05.2020, ÖE-1155. \\
\hline
\end{tabular}

\subsection{Anatomical Study}

Anatomical studies were carried out on aerial parts (stem and leaf) of taxa kept in $70 \%$ ethanol. The sections were studied and photographed from the preparations were taken with a LEICA (DFC 450C \& DM 2500) microscope.

\section{Results and Discussion}

\subsection{Stem Anatomy}

Sambucus nigra: In the section taken from the stem, there is a thick cuticle layer outside the stem. The margin of stem is straight in $S$. nigra. There are eglandular hairs on the epidermis. The epidermis is composed of a single row of regularly arranged epidermal cells. The vascular bundles in the body of the plant are regular. Collenchyma is located under the epidermis. Collenchyma is composed of 7-12 layers. Cortex 8-10 layered and the cells are ovoidal or circular. Phloem is composed of 4-8 layers of cells. Xylem is composed of 9-12 layers of cells. Cambium is distinguishable and 3-5 layered. The sclerenchymatic cells in the stem are thickened and their spaces are narrow. The pith in the stem is composed of large cells and there is little or no intercellular space. (Figure 1).

Sambucus ebulus: In the cross section taken from the stem of the plant, the cuticle layer was seen on the outer part of the stem. The margin of stem is most partly straight and partly wavy in S. ebulus. Epidermis cells are arranged in a single row and there are eglandular hairs on them. Epidermal cells are also found under the cortex layer. Collenchyma is composed of 3-7 layers. Phloem is composed of 4-7 layers of cells. Xylem is composed of 6-9 layers of cells. Cambium is distinguishable and 3-4 layered. The vascular bundles in the stem of the plant are arranged regularly. There are large parenchymatic cells in the pith region and little or no pith cavity (Figure 2).

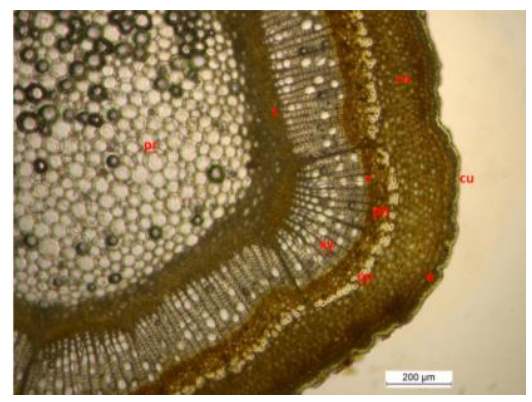


Figure 1. Cross-section of stem of S. nigra (ph: phloem, xy: xylem, $t$ : trachea, pr: pith region, cu: cuticula, e: epidermis, co: collenchyma, en: endodermis, c: cambium)

Şekil 1. S. nigra gövde enine kesiti (ph:floem, xy:ksilem,t:trake, pr:̈̈z bölgesi, cu:kutikula, e: epidermis, co: kollenkima, en: endodermis, $c$ : kambiyum)

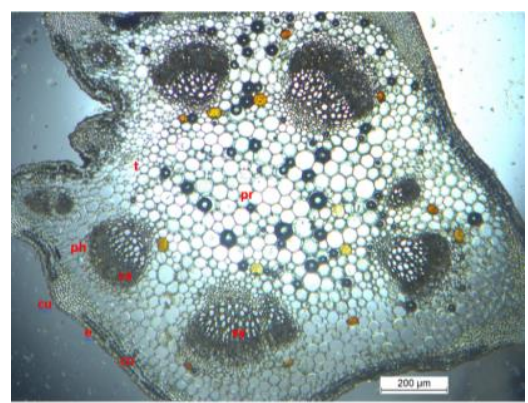

Figure 2. Cross-section of stem of S. ebulus (ph: phloem, xy: xylem, $t$ : trachea, pr: pith region, cu: cuticula, e: epidermis, co: collenchyma, en: endodermis, ca: cambium)

Şekil 2. S. ebulus gövde enine kesiti (ph: floem, xy: ksilem, $t$ : trake, pr: öz bölgesi, cu: kutikula, e: epidermis, co: kollenkima, en: endodermis, c: kambiyum)

\subsection{Leaf Anatomy}

Sambucus nigra: In upper and lower cross section of leaf, there is a thin cuticula layer in the outermost of leaf. The stomata are anemocytic type and they observed on the abaxial surface. The leaf showed a bifacial leaf anatomical structure. There are glandular hairs on the adaxial surface. Glandular hairs are mostly seen in the adaxial surface and not in the abaxial surface. The vascular bundles are surrounded by a parenchyma cells consisted of druse crystals. The epidermis cell shape were examined puzzle-shaped on abaxial and adaxial surface of the leaf (Figures 3,4).

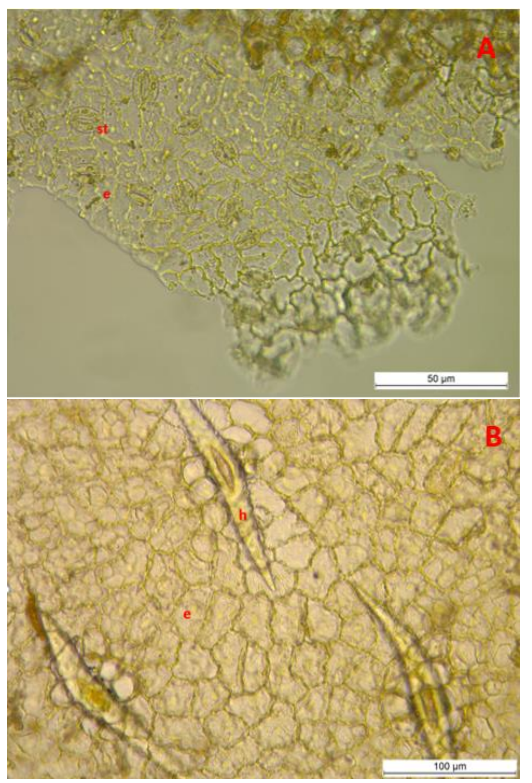

Figure 3. Superficial section of lower surface (A) and upper surface (B) of leaf of S. nigra (st: stoma, e: epidermis, $h$ : hair) Şekil 3. S. nigra yaprak alt yüzey (A) ve üst yüzeyin (B) yüzeysel kesiti (st: stoma, e: epidermis, $h$ : tüy)

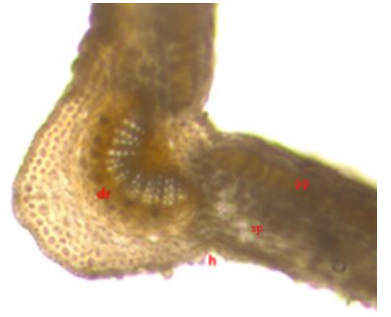

$200 \mathrm{vm}$

Figure 4. Cross-section of leaf of $S$. nigra(pp: palisade parenchyma, sp: spongy parenchyma, $h$ : hair, dr: druse crystals) Şekil 4. S. nigra yaprak enine kesiti (pp: palizat parankimasi, sp: havalandırma parankiması, h:tüy, dr: druz kristalleri)

Sambucus ebulus: There is a thin cuticle for both upper and lower epidermis in the cross-sections of leaf. Stomata are observed in the lower part of the leaf which type of anomocytic. The leaf showed a bifacial leaf anatomical structure. There are not glandular hairs on the upper surface. The vascular bundles are surrounded by a parenchyma cells consisted of druse crystals. There are glandular or eglandular hairs on the lower and upper epidermis. The glandular and eglandular hairs are denser in the lower epidermis than in the upper epidermis. The epidermis cell shape were examined puzzle-shaped on abaxial surface and oblong on adaxial surface of the leaf (Figures 5, 6).

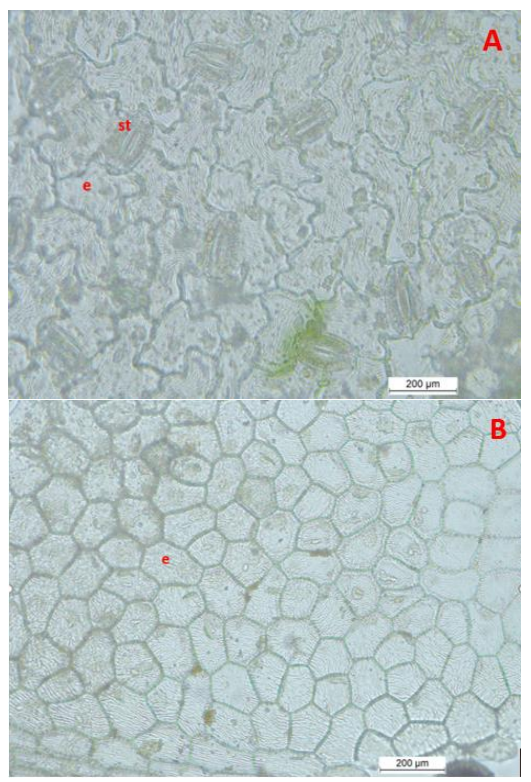

Figure 5. Superficial section of lower surface (A) and upper surface (B) of leaf of S. ebulus (e: epidermis, st: stoma) Şekil 5. S. ebulus yaprak alt yüzey (A) ve üst yüzeyin (B) yüzeysel kesiti (e: epidermis, st: stoma)

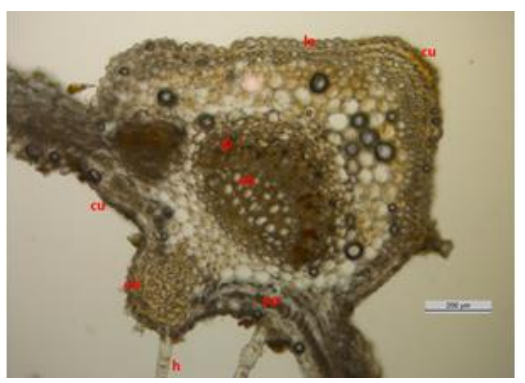


Figure 6. Cross-section of leaf of S. ebulus (cu: cuticle, le: lower epidermis, ue: upper epidermis, pp: palisade parenchyma, sp: spongy parenchyma, vb: vascular bundle, $h$ : hair, dr: druse crystals)

Şekil 6. S. ebulus yaprak enine kesiti (cu: kutikula, le: alt epidermis, ue: üst epidermis, pp: palizat parankimasl, sp: havalandırma parankiması,vb: iletim demetleri, h:tüy, dr: druz kristalleri)

Taxonomic studies of the Sambucus genus have been carried out in different parts of the world, but this study was carried out for the first time with samples from Turkey [4,8]. According to the results of the study, taxa showed great similarities and no significant anatomical differences were observed. Both species showed a bifacial leaf anatomical structure and anomocytic stomata. The number of vascular bundles, arrangement of druse crystals, adaxial and abaxial cell shapes of leaf, margin of stem, the number of collenchyma were showed differences characters for taxa. In cross section of stem of $S$. nigra, the number of vascular bundles and collenchyma were thicker than $S$. ebulus. Also, in $S$. nigra arrangement of druse crystals were more regular than $S$. ebulus. Some scientific reports have shown that stomata type, leaf anatomical structure, cell shape similarity as our study. As a result of anatomical studies, the long-term secondary growth is understood from the composition of the cortex structure. When the literature was examined, it was seen that this issue was emphasized in the studies [24-29]. Anatomical studies of this genus have shown that crystals are a taxonomically important character for the genus [4, 30-33].

The results of present and others studies show that the number of vascular bundles, anomocytic stomatas and existence the druse crystals are diagnostic characters in studied species. Although, many features in two species are identical, there are some anatomical variations between $S$. nigra and $S$. ebulus. Our observations are in accordance with previous records in other Adoxaceae or Caprifoliaceae elements [2,34,35].

\section{Conclusions and Recommendations}

In this study, comparative anatomical were investigated taxa of Sambucus. The data obtained from the current anatomical study will facilitate the identification of two taxa and will provide new taxonomic contributions. It will also be a reference for new studies on this genus. In future studies, it is recommended to take SEM photographs of seed and glandular hairs in order to increase anatomical similarities and differences.

\section{References}

[1] Mabberley, D. J. (2008). Mabberley's Plant-book: a portable dictionary of plants, their classifications and uses (No. Ed. 3). Cambridge University Press.

[2] Amini, E., Nasrollahi, F., Sattarian, A., Isazadeh-Araei, M., \& Habibi, M. (2019). Systematic and molecular biological study of Sambucus L.(Caprifoliaceae) in Iran. Thaiszia - J. Bot., Košice, 29 (2): 133-150.

[3] Donoghue, M. J., Bell, C. D., \& Winkworth, R. C. (2003). The evolution of reproductive characters in Dipsacales. International Journal of Plant Sciences, 164(5), 453-464.

[4]Amini, E., Nasrollahi, F., Sattarian, A., Isazadeh-Araei, M., Habibi, M. (2021). Morphological and anatomical study of the genus Sambucus L. (Adoxaceae) in Iran. Modern Phytomorphology, 15: 15-19.

e-ISSN: 2148-2683
[5]Applequist, W. L. (2013). A brief review of recent controversies in the taxonomy and nomenclature of Sambucus nigra sensu lato. In I International Symposium on Elderberry, 1061, 25-33.

[6] Schwerin, F.G. (1920). Revisio generis Sambucus. Mitt Deutsch Dendrol Ges, 29:194-231.

[7] Bolli, R. (1994). Revision of the genus Sambucus. Dissertationes botanicae, 223. J. Cramer, 256.

[8] Wrońska-Pilarek, D., Jagodziński, A. M., Bocianowski, J., Marecik, M., \& Janyszek-Sołtysiak, M. (2020). Pollen morphology and variability of Sambucus nigra L.Adoxaceae. Biologia, 75(4), 481-493.

[9] Türkmenoğlu, G. , Sarkaya, A. G. \& Fakir, H. (2019). Phlomis grandiflora H. S. Thompson var. grandiflora ve Phlomis leucophracta P. H. Davis \& Hub.-Mor. Taksonlarının Farklı Toplama Zamanlarına Ait Uçucu Bileşenleri . Avrupa Bilim ve Teknoloji Dergisi , (17) , 145151 .

[10] Atay, I., Kirmizibekmez, H., Gören, A. C., \& Yeşilada, E. (2015). Secondary metabolites from Sambucus ebulus. Turkish Journal of Chemistry, 39 (1), 34-41.

[11] Güner, A., \& Aslan, S. (Eds.). (2012). Türkiye bitkileri listesi:(damarlı bitkiler). Nezahat Gökyiğit Botanik Bahçesi Yayınlar1.

[12]Yesilada, E., Gürbüz, İ., \& Toker, G. (2014). Antiulcerogenic activity and isolation of the active principles from Sambucus ebulus L. leaves. Journal of ethnopharmacology, 153(2), 478-483.

[13] Senica, M., Stampar, F., Veberic, R., \& Mikulic-Petkovsek, M. (2016). Processed elderberry (Sambucus nigra L.) products: A beneficial or harmful food alternative?. LWTFood Science and Technology, 72, 182-188.

[14] Akbulut, M., Ercisli, S., \& Tosun, M. (2009). Physicochemical characteristics of some wild grown European elderberry (Sambucus nigra L.) genotypes. Pharmacognosy magazine, 5(20), 320.

[15] Ağalar, H. G. (2019). Elderberry (Sambucus nigra L.). In Nonvitamin and Nonmineral Nutritional Supplements (pp. 211-215). Academic Press.

[16] Jabbari, M., Daneshfard, B., Emtiazy, M., Khiveh, A., \& Hashempur, M. H. (2017). Biological effects and clinical applications of dwarf elder (Sambucus ebulus L): A review. Journal of evidence-based complementary \& alternative medicine, 22(4), 996-1001.

[17] Manganelli, R. U., Zaccaro, L., \& Tomei, P. E. (2005). Antiviral activity in vitro of Urtica dioica L., Parietaria diffusa $\mathrm{M}$. et $\mathrm{K}$. and Sambucus nigra L. Journal of Ethnopharmacology, 98(3), 323-327.

[18] Merica, E., Lungu, M., Balan, I., \& Matei, M. (2006). Study on the chemical composition of Sambucus nigra L., essential oil and extracts. NutraCos, 5(1), 25-27.

[19] Novelli, S. (2003). Developments in berry production and use. Bi-weekly Bull. Agric. Agri-Food Canada, 16, 21.

[20] Faniyan, M.M., Olatunde, D.O., Ayeni, O.B., Jimoh, M.A., Saheed, S.A. (2013). Functional leaf anatomical characters in relation to $\mathrm{C} 3$ and $\mathrm{C} 4$ photosynthetic pathways in four species of Euphorbia L. in Southwestern Nigeria. Nigerian journal of botany, 26(1): 19-28.

[21] Ayeni, O. B., Jimoh, M. A., \& Saheed, S. A. (2015). Leaf anatomical characters in relation to the $\mathrm{C} 3$ and $\mathrm{C} 4$ photosynthetic pathway in Cyperus (Cyperaceae). Nordic Journal of Botany, 33(3), 318-323. 
[22] Ajao, A. A. N., Jimoh, M. A., \& Saheed, S. A. (2017). Studies on anatomical characters indicating C 3 and C 4 photosynthetic metabolism in the genus Boerhavia L.(Nyctaginaceae). Taiwania, 62(3).

[23] Davis, P. H. (1970). Flora of Turkey and the East Aegean Islands. Vol. 3. Flora of Turkey and the East Aegean Islands. Vol. 3.

[24] Esau, K. (1967). Plant Anatomy. John Willey \& Sons. Inc., New York.

[25] Fahn, A. (1967). Plant anatomy. Plant anatomy. Pergamon Press, New York.

[26] Metcalfe, C.R,. Chalk, L.(1972). Anatomy of Dicotyledons. Clarendon Press, Oxford.

[27] Özörgücü, B., Gemici, Y., \& Türkan, İ. (1991). Karşılaştırmalı Bitki Anatomisi. Ege Üniversitesi, Bornova, İzmir.

[28] Özörgücü, B. (1993). Bitki Morfolojisi ve Anatomisine Giriş. Ege Üniv. Fen Fak. Kitapları Serisi, (136).

[29] Yentür, S. (1995). Bitki Anatomisi. İstanbul Üniv. Fen Fak. Yay., İstanbul.(in Turkish).

[30]Metcalfe, C.R., Chalk, L.(1950). Anatomy of the Dicotyledons. Oxford Univ. Press, London, Vol. 2.

[31]Fahn, A. (1990). Plant Anatomy, Fourty edition, Butterworth, Heinemann Pub. Ltd., Jarusalem, Israel.

[32] Sargın, S. A., \& Selvi, S. (2016). Türkiye'de yayılış gösteren Cistus L.(Cistaceae) cinsinin karşılaştırmalı yaprak anatomisi. Iğdır Univ. J. Inst. Sci. \& Tech. 6(2): 41-48.

[33] Selvi, S., Aladi, H. I., \& Paksoy, M. Y. (2019). Micromorphological and anatomical investigations on Conringia Heist. ex Fabr. Bangladesh Journal of Botany, 48(4), 1153-1162.

[34] Scopel, M., Nunes, E., Vignoli-Silva, M., Vendruscolo, G. S., Henriques, A. T., \& Mentz, L. A. (2007). Caracterização farmacobotânica das espécies de Sambucus (Caprifoliaceae) utilizadas como medicinais no Brasil. Parte I. Sambucus nigra L. Revista Brasileira de Farmacognosia, 17, 249-261.

[35] Rugina, R., \& Toma, C. (2007). Histo-anatomical aspects of some Lonicera L. species. Analele Stiintifice ale Universitatii" Al. I. Cuza" din Iasi, 53, 26. 